\title{
Architectural Heritage in the Areas of Industrial Development of the Lower Angara Region: Stages of Formation and Problems of Preservation
}

\author{
Vladimir V. Tsarev ${ }^{1,2, *}$ Vladimir I. Tsarev ${ }^{1,3, a}$

\begin{abstract}
${ }^{1}$ Scientific Research Institute of Theory and History of Architecture and Urban Planning (NIITIAG), Branch of the Federal State Budget Institution "Central Scientific-Research and Project Institute of the Construction Ministry of Russia", Moscow, Russia

${ }^{2}$ Department of Urban Development of the Ministry of Construction of the Krasnoyarsk Territory, Moscow-Krasnoyarsk, Russia

${ }^{3}$ Siberian Federal University, Moscow-Krasnoyarsk, Russia

aEmail: vits_2004@mail.ru

*Corresponding author.E-mail: tsarev103@yandex.ru
\end{abstract}

\begin{abstract}
The article deals with the problems of preserving the architectural heritage caused by the new stage of industrialization of Central Siberia that began in the 21st century. The construction of the Boguchanskaya HPS (hydroelectric power station) on the Angara River and the development of natural resources in the region entail the threat of disappearance of the last pockets of identity of the Siberian region. In the area of flooding of the reservoir were almost all coastal historically developed settlements. The results of the study conducted by the authors demonstrate the uniqueness of folk architecture that has survived to the present time on the vast territory of the Angara river basin. The developed principles of disclosure of the historical and cultural value of the Lower Angara region's heritage allow us to include in the structure of the created territorial-industrial complex identified villages - centers of concentration of cultural heritage objects.
\end{abstract}

Keywords: industrialization, architectural heritage, Central Siberia, Angara region, culture of Siberian oldresidents, methods of preservation of architectural heritage

\section{INTRODUCTION}

The oldest centers of Russian development of the Siberian lands disappeared in the waves of the reservoir of the next Boguchanskaya HPS, built on the Angara in the early $21 \mathrm{st}$ century. Together with them, only according to official data, almost one and a half hundred objects of historical, cultural and archaeological heritage taken under state protection and newly identified disappeared. The current situation indicates that the remaining material signs of the development of Russian national culture in the Lower Angara region need further deep and comprehensive study, and early measures to preserve them. The relevance of the research carried out by the authors is determined by the significance of the Angara traditions in the culture of Siberia and a small number of in depth

*Fund: This paper was funded by the Program of Fundamental Researches of the Ministry of Construction, Housing and Utilities of the Russian Federation and the Russian Academy of Architecture and Construction Sciences 2020, the Research Project 1.2.20. scientific works on the history of architecture of populated areas of the territory under consideration. Generalization of data from field and archival research allows us to conclude that the fundamental feature of settlement, settlement planning and peasant architecture of the Lower Angara region is the historical continuity, manifested in the preservation and maintenance of cultural traditions introduced here at the early stage of Russian settlement in the Siberian lands.

II. STAGES OF SETTLEMENT FORMATION ON THE BANKS OF THE UPPER TUNGUSKA (ANGARA) IN 17TH - EARLY 20TH CENTURY

The results of the analysis of the Russian settlement along the Upper Tunguska (Angara) in the 17-18th centuries reveal its importance as the most important waterway between Western and Eastern Siberia, which contributed to the accelerated progress of the pioneers on unknown lands, determine the main centers of the initial stage of settlement on the Angara banks [1]. The successive penetration of Russian service people from 
the mouth to the source of the Upper Tunguska (Angara) led to the construction of the ostrog Rybinsk (1628), Ilimsky (1630), Bratsky (1631) and Irkutsk (1661), which became the key points in the system of river communications, and allowed the Russians to finally gain a foothold in Eastern Siberia.

The authors revealed that at the turn of the 19-20th centuries on the banks of the lower and middle Angara (to the mouth of the river Ilim) there were 57 Russian settlement, of which there were 11 villages, 45 hamlet and one winter quarters. They were mainly oldresidents villages who had emerged in the first centuries of the Russian development of Siberia. Most of the settlements of the Lower Angara region (34 out of 57) were confined to the mouths of the Angara tributaries "mouth type". Other settlements: "coastal" - 7 and "cape" - 4 villages. It should be noted the island's twelve villages. This type of settlement is unique, as it is rarely found elsewhere in Siberia. Currently, most of the islands and villages on them are flooded by the reservoirs of Bratskaya, Ust-Ilimskaya and Boguchanskaya HPS.

\section{FORMATION OF VILLAGES OF THE LOWER ANGARA REGION IN THE 17TH - EARLY 20TH CENTURY}

In the 17th century the first Russian villages on the banks of the Siberian rivers Yenisei and Upper Tunguska (Angara) were wooden fortresses-ostrog. The main fortress on the water-land road linking the $\mathrm{Ob}$, Yenisei and Upper Tunguska rivers (Angara) was the Yenisei ostrog, the stages of formation of which are traced by archival documents of the 17-18th centuries [2]. On the Ob-Yenisei-Angara way, in addition to the Yenisei fortress, important fortified points were Makovsky, Bolsheelansky, Rybinsky and Bratsky ostrogs, about the structures of which documentary information was revealed, indicating the existence of common methods and techniques for building Russian wooden fortresses.

In the $1660 \mathrm{~s}$, following the construction of a system of fortresses on the Ob-Yenisei-Angara road, measures were taken under the control of the state authorities to create agricultural villages, with the help of which it was supposed to provide military garrisons with the main type of food - bread. The analysis of archival documents showed that the main structural and planning element of the Siberian agricultural villages in the second half of the 17th century was the yard, which united residential and economic buildings, around which the territory of the life of the peasants was formed. Among the residential buildings in the documents stand out huts that existed in all the villages under consideration. The second type of residential structure was - "crate". Farm buildings that were located in the first agricultural villages can be divided by their location into: farmsteads, located within the yard (stable, flock, povet, barn); street, set "against the yard on the street" (barn, cellar, bath); local, standing at some distance from the village yards (threshing floor, ovin, riga, mill).

In the 18th century, as shown by the analysis of archival documents, the development of villages of the Yenisei district was formed, as in the previous century, residential and economic buildings, united by yard space. A significant part of the area of courtyards began to occupy gardens. In the typology of residential buildings can be traced the appearance in the structure of the house, along with the hut, the second warm room - the gornitsa. Further spread were three-chamber dwellings (house-connection), consisting of one warm part (hut, the gornitsa), which was attached to the unheated parts of the house - the canopy and the crate. A characteristic feature of Russian housing in the Yenisei district was the significant size of the area of residential buildings, reaching 70-150 square meters.

At the beginning of the 19th century, along with the first regulatory documents in the Siberian provinces, a new term appeared - farmstead, replacing the former name of the main cell of the planning structure of villages - peasant household. It was revealed that old resident of the village of the Lower Angara region developed from a free plan form to a coastal-linear layout. In the nineteenth century, when the life of rural settlers increasingly began to be subject to control by the official authorities, a new type of planning - street one- and two-way.

Island villages sometimes developed a type of structure that can be called "ring" or "circular". The process of its formation is explained, first, by the faster addition of the structure (due to the limited area of development); second, by the obvious need to allocate its center of formation in conditions of relative isolation from the rest of the land.

In the 19th century, the most common type of manor Angarsk peasant was a complex of buildings with two courtyards, which are adjacent to the sides of the house. To the street end facade was located hut, which is the opposite facade (in the case of the houseconnection) through the canopy connected to the gornitsa. On one side of the house were grouped barns and sheds around a part of the territory, which was called a clean yard, paved with logs or boards, which had a separate gate to the street. On the other side of the house adjoined a covered barnyard (prigon). At the back of the yard were cold rooms for cattle, sheds, barns. The baths were located in the garden or on the bank of the river. Another variation of the Angara peasant estate of the nineteenth century was a variant of the layout, in which there was a single yard, located on the side of the hut, facing the street end side [3]. 


\section{THE PECULIARITY OF THE PEASANT ARCHITECTURE OF THE LOWER ANGARA REGION OF THE 17TH - EARLY 20TH CENTURY}

The survey by the authors of old settlements of the Lower Angara region recorded residential buildings: single house (crate, chetyrehstennoy); long house (triple), five-wall log hut; the "round house" (the local version of six-string crosspiece); a two-story house. The main elements of the interior of peasant houses in Angara villages are revealed: stoves, coloring and painting of the walls, the location of the red corner.

In the studied part of the Angara region, there are three main types of barns - single-chamber four-walls, two-chamber five-walls and three-chamber six-walls, which in turn are divided into one-story and two-story. Recorded types of outdoor buildings farm houses; buildings for cattle, baths, podnavesya.

Until the end of the 19th century, residential and farm buildings in the Angara region were built using $\log$ and columnar structures, the technical details of which were common to all types of buildings. Many of them were brought to the Siberian lands by the first Russian settlers. For residential premises, cells were used, chopped "in oblo" with the remainder. Less common cutting "in the paw". The roofs had male pediments (the local name of the versheniya), for the device of which sometimes used the halves of a log cut in two, block. To give strength to the gable, recruited from the blocks, a special device was used wedgesinserts, cut into one-third of the width of adjacent logs. Redwood residents call these wedges as "paclami".

In the house carving of Angarsk villages more used hollowed and volume-modeled carving, while widespread in the early 20th century, cutting was less common. In the old huts were arranged oklopna and felled-brackets, depicting a stylized head of a horse. Usually there are fells-brackets with rollers on the ends of each log. The basis of the color scheme of buildings was the natural color of wood. The types of windows, doors, porches, carved elements of peasant houses and farmstead gates are studied.

The features of religious architecture in the old-age villages of the Lower Angara region are considered [4]. Wooden churches and chapels were built from the 17th century to the first decade of the 20th century. Field surveys have shown that wooden churches in a dilapidated form have survived to the present day in some villages located away from the Angara, on its tributaries, in the villages of Bidee, Yarkino and Yurokhte of the Kezhem district, and now they are one of the few old buildings of the disappearing villages

At the turn of the 18-19th centuries in large villages of the Lower Angara region were built stone churches (Chadobets, Kezhma, Boguchany, Rybinsk,
Kashinoshiverskoe), architectural and construction history of which is revealed in the study of documentary sources. Their architectural and planning features are typical for the stone architecture of Siberia of that period and the buildings of the "Yenisei circle" associated with the formation of the style direction of the 18th century - Siberian Baroque. To date, stone churches have not been preserved in the Lower Angara region. The ruined remains of the last of them - the Spasskaya Church in the village of Kezhma - were flooded by the Boguchanskaya HPS reservoir in 2014.

In the 20th - early 21 st century in the architecture of the villages of Siberian old residents there were significant losses, as a huge number of villages were in the areas of flooding reservoirs of hydroelectric power plants, continuously built since the 1950s. In connection with the construction of hydroelectric power plants and their harmful impact on the primordial identity of the Siberian region in the scientific, creative and social environment, special importance began to acquire questions about the wide study and fixation of monuments of old-time culture, and the most valuable examples of this folk art were offered to preserve [5]. The authors propose options for preserving the architectural heritage in the region under consideration, one of which may be the creation of territories in a single structure of the Lower Angara region, which will focus on historical and cultural objects. Here should be collected the most valuable examples of complexes of residential estates, individual objects of religious and economic purpose, taken out of the zones of active industrial development. The implementation of this concept will increase the architectural, cultural and economic significance of the area of new industrial development of Siberia.

\section{CONCLUSION}

The results of the study clearly demonstrate the uniqueness of folk architecture that has survived to the present time on the vast territory of the Angara river basin. Geographical location, climatic conditions, demographic and socio-economic situation - all this has affected the formation and preservation of the oldtimers core of the Russian population with its original material and spiritual culture in the area. The organizing principle in the planning of villages was the river, which determined the transformation of the free form of the plan in the coastal-linear layout of most oldtime settlements. The peculiarity of settlement on the Angara in the period under review was the island villages, which represented one of the most ancient types of Russian villages in the region.

The interaction of North Russian, Central Russian and local traditions of folk architecture is one of the reasons for the formation of characteristic features of the architecture of the Lower Angara region, among 
which the following should be distinguished: a closed, open-top courtyard, large-scale manor buildings, their similar typology. Along with common features of folk architecture Siberia, built in the Lower Angara region have local features expressed by the planning decisions (for example, the length of the low height of the building), and simple architectural details, in general simplicity and rigor of the forms of peasant structures surrounded by a harsh and along with the magnificent Siberian landscape.

Preservation of the architectural heritage as a component of the originality of the appearance of settlements, reflection of historical forms of interaction and connections of architecture with the landscape is one of the most important conditions for sustainable development of settlements in the region, continuity of cultural values of the environment in the process of formation of new values. The developed principles of disclosure of historical and cultural heritage values are based on historical, natural and socio-economic prerequisites that exist in the Lower Angara region, which allow to include in the structure of the created territorial-industrial complex identified villages centers of concentration of cultural heritage objects (for example, the villages of Yarki, Kamenka, Goltyavino, Syromolotovo, Zaledeevo, Klimino, Chadobets). Architectural and spatial expositions of wooden architecture monuments and thematic complexes of the unified network of open-air museums will provide a new quality of development of the cultural potential of the Lower Angara region's heritage on the basis of the inseparable connection of historical-documentary and artistic-figurative components of architecture with the forms of the natural landscape.

Further development of the topic may involve indepth research on the creation of a town-planning concept for the preservation of the architectural and historical heritage of the Lower Angara region in the framework of the formation of various types of tourism, taking into account the socio-economic factors of the region's economy. Its implementation will create new jobs, expand the tourist and transport infrastructure, and include the heritage of the Lower Angara region in the overall network of tourist routes in Siberia.

\section{References}

[1] V.V. Tsarev, The Formation of Russian Settlements in Angara Region in the 17-19th Centuries in: Vestnik of Tomsk state university of architecture and building, 2016, No. 6, pp. 44-55 [In Russian].

[2] V.I. Tsarev, V.V. Tsarev, Stages of architectural and planning transformations of the Yenisei Ostrog according to documents of the 17-18th centuries in: Fundamental, search and applied research of the RAASN on scientific support for the development of architecture, urban planning and construction industry of the Russian Federation in 2017, vol. 1, Moscow: ACB publishing House, 2018, pp. 248-253 [In Russian].
[3] V.V. Tsarev, V.I. Tsarev, Peasant architecture in the villages of the Lower Angara region: a comparative analysis of research in: Balandin readings: collection of articles of scientific readings in memory of S.N. Balandin, April 15-18, 2014, Novosibirsk, Novosibirsk. state archit.-thin. Acad., 2014, Vol. 9, part 1, pp. 39-42 [In Russian].

[4] V.V. Tsarev, Church Architecture in Settlements of Lower Angara in the 17th and Early 20th Century in: Vestnik of Tomsk state university of architecture and building, 2016, No. 4, pp. 45-54 [In Russian]

[5] V.V. Tsarev, V.I. Tsarev, Problems of Preservation of Architectural Heritage in the Areas of Industrial Development of Siberia in: Advances in Social Science, Education and Humanities Research, vol. 324, International Conference on Architecture: Heritage, Traditions and Innovations (AHTI 2019), pp. 362-365. 